\title{
Chinese herbal Jin-Ying-Tang attenuates the inflammatory response by inhibiting the activation of TLR4/MyD88/TRAF-6/NIK pathway at the mRNA level in LPS-stimulated mouse mammary epithelial cells
}

\author{
Qiong $\mathrm{Yi}^{1}$, Xin $\mathrm{Li}^{1,2}$, Yuan-Fang $\mathrm{Li}^{1,3}$, Hang Yang ${ }^{1,2}$, \\ Xiao-Yi Zhang ${ }^{1,2}$, Zhe Ma ${ }^{1,3}$, Lu Wang ${ }^{1}$ \\ ${ }^{1}$ Biochemical Engineering Center of Guizhou Province, \\ ${ }^{2}$ College of Animal Science, \\ Guizhou University, 550025 Guiyang Guizhou, People's Republic of China \\ ${ }^{3}$ Institut für Prophylaxe und Epidemiologie der Kreislaufkrankheiten, Klinikum der Universität München, \\ Ludwig-Maximilians-Universität München, D-80336 München, Germany \\ wanglu7007@163.com
}

Received: September 29, 2015 Accepted: February 19, 2016

\begin{abstract}
Introduction: The effects of Jin-Ying-Tang (JYT) on Toll-like Receptor 4 (TLR4) signalling transduction of lipopolysaccharide (LPS)-stimulated mouse mammary epithelial cells (MECs) in vitro were examined. Material and Methods: The cytotoxicity of JYT $(0.06-62.50 \mathrm{mg} / \mathrm{mL})$ on mouse MECs was determined by MTT assay. The MECs were co-cultured with LPS in the presence or absence of JYT $(39.10 \mu \mathrm{g} / \mathrm{mL}, 391 \mu \mathrm{g} / \mathrm{mL}, 3910 \mu \mathrm{g} / \mathrm{mL})$. The concentrations of interleukin-6 (IL-6) and tumour necrosis factor- $\alpha(\mathrm{TNF}-\alpha)$ in the culture supernatants were detected by ELISA. The mRNA expression of TLR4 and downstream TLR4 signalling molecules such as myeloid differentiation factor 88 (MyD88), tumour necrosis factor receptor associated factor 6 (TRAF-6), inhibitor $\kappa \mathrm{B}$ (I $\kappa \mathrm{B}$ ), and nuclear factor $\kappa \mathrm{B}$ inducing kinase (NIK) were determined by quantitative real-time polymerase chain reaction (qRT-PCR). Results: The results showed that the $\mathrm{IC}_{50}$ of JYT on MECs was $12.25 \mathrm{mg} / \mathrm{mL}$ and JYT could significantly decrease the concentrations of IL-6 and TNF- $\alpha$ in LPS-stimulated MECs $(\mathrm{P}<0.05)$. The mRNA expression of TLR4, MyD88, TRAF-6, IאB, and NIK was also significantly decreased when the LPS-stimulated MECs were cocultured at appropriate concentrations of JYT $(\mathrm{P}<0.05, \mathrm{P}<0.01)$. Conclusion: These observations indicate a potential mechanism through which JYT attenuates the systemic inflammatory response to LPS-stimulated mouse mammary epithelial cells by inhibiting the activation of TLR4/MyD88/ TRAF-6/NIK pathway at the mRNA level.
\end{abstract}

Keywords: mouse, JYT, mammary epithelial cells, cytokine, mRNA expression, signalling transduction.

\section{Introduction}

Mastitis is one of the most epidemic, frequent, and costly infectious diseases affecting the dairy cattle industry worldwide. It is an infection of the udder caused by a variety of different bacteria and fungi (such as Staphylococcus aureus, coliforms) entering the mammary gland via the teat canal (3). During the incidence of mastitis, mammary gland immunity plays an important role in the prevention of microbial invasion, as the first line of defence. Mammary epithelial cells (MECs) together with macrophages are capable to respond to bacterial intrusion and play a major part in the initiation of inflammation (32). A key component of the host innate immune response to mastitis is a rapid increase in concentrations of cytokines, such as IL-6, IL-8, IL-1 $\beta$, and TNF- $\alpha$ in milk. These cytokines can attract neutrophils to the site of infection and provide defence against invading mastitis pathogens $(22,23)$. Stimulation of bovine MECs with LPS for $24 \mathrm{~h}$ elicited a marked increase in mRNA expression of IL-1 $\beta$, IL-6, TNF- $\alpha$, CXCL6, and 
$\beta$-defensin. Furthermore, differential cytokine and chemokine responses of bovine MECs to lipoteichoic from Staphylococcus aureus and LPS from Escherichia coli $(7,16,27)$ indicate that MECs play an important role in the mammary gland immunity.

Toll-like receptors (TLRs) are members of the pattern-recognition receptors family that detect specific molecules associated with microbial pathogens. Their activation leads to the mobilisation of other innate immune molecules such as cytokines, chemokines, and interferons $(2,19)$. TLRs activate signalling through the Toll/interleukin-1 receptor (TIR) domain, which in turn triggers the binding of the TIR domain-containing adaptors, including MyD88, TIR domain containing adaptor protein (TIRAP), TIR domain-containing adapter-inducing IFN- $\beta$ (TRIF), and Trif-related adaptor molecule (TRAM), activating specific signalling pathways $(13,20)$. MyD88 activates the IL-1 receptor associated kinases (IRAKs). IRAKs in turn activate TRAF-6, and elicit downstream signalling via the nuclear factor $\kappa \mathrm{B}(\mathrm{NF}-\kappa \mathrm{B})$ pathway (36). TLR4 is a prominent member of the TLR family of host receptors $(1,18)$. LPS, a major component of the cell wall of Gram-negative bacteria, is able to bind to TLR4, resulting in activation of the transcription factor $\mathrm{NF}-\kappa \mathrm{B}$ via signal transduction cascades. MyD88- and TRAF-6-deficient mice display hyporesponsiveness to both IL-1 and LPS $(14,17)$. Finally, NF- $\kappa B$ is then free to translocate to the nucleus and induces the expression of various pro-inflammatory cytokines (such as TNF- $\alpha$, IL-1 $\beta$, IL-6, and IL-8) (6).

Nowadays, development of antibacterial and immunomodulatory potential of natural products to replace the application of antibiotics in bovine mastitis have become mainstream in the prevention of mastitis in modern dairy industry $(3,26)$. Jin-Ying-Tang (JYT) is an empirical formula that was developed based on the principles of traditional Chinese medicine (TCM) and is used to treat mastitis in dairy cattle. This formula has obtained a national invention patent (Patent no.: ZL 20101 0554152.8). JYT consists of the following herbs: macranthoides Hand.-Mazz., flower; Taraxacum mongolicum Hand.-Mazz., whole plant; Trichosanthes kirilowii Maxim., fruit; Forsythia suspensa (Thunb.) Vahl., fruit; Rheum officinale Baill., root; Astragalus membranaceus (Fisch.) Bunge., root; and the root of Angelica sinensis (Oliv.) Diels., which have all been proven to possess many biological activities, including anti-inflammatory, immunomodulatory, and antibacterial properties $(34,35)$. We have reported that the cure rate and the effective rate of the JYT injection in subclinical mastitis in dairy cattle were $53.8 \%$ and $92.3 \%$ respectively (30). JYT injections also exhibited favourable efficacy in Staphylococcus aureus-induced mastitis in rabbits and significantly decreased the TNF- $\alpha$ and IL- 6 concentrations in serum and mammary glands (31). However, the precise mechanism of its anti-inflammatory activity remains largely unclear. Therefore, in this study, we have evaluated the effect of
JYT on LPS-induced inflammation in MECs and its underlying anti-inflammatory mechanism from the perspective of LPS-TLR4/ NF- $\mathrm{BB}$ signalling pathway, such as the expression of TLR4, MyD88, TRAF-6, $\mathrm{I} \kappa \mathrm{B}$, and NIK, hoping to provide a theoretical basis for further research on JYT and its application in prevention or therapy of mastitis.

\section{Material and Methods}

Reagents and instruments. Mouse TNF- $\alpha$ and IL-6 ELISA kits were purchased from IBL, Germany. Power SYBR Green PCR Master Mix - from AB, UK, and FCS were acquired from Zhejiang Tianhang, China. TIANScript cDNA kit was purchased from Beijing TIANGEN, China. RNA extraction kit, EsTaq MasterMix, was procured from Beijing Kangwei, China. The qTOWER 2.0/2.2 Real Time PCR System was made in Analytic Jena AG, Germany. Thermo Scientific Multiskan ${ }^{\text {TM }}$ GO Microplate Spectrophotometer was made in Thermo Fisher Scientific Oy, Finland, and IX-71 inverted phase contrast microscope in Olympus, Japan.

Animals. Ten to 12-week-old, mid-pregnant Kunming mice were used. The mice were purchased from the Medical Experimental Animal Centre of Daping Hospital, Research Institute of Surgery of the Third Military Medical University, Chongqing. They were housed in micro isolator cages, receiving standard laboratory animal feed and water ad libitum. The experiments followed the guidelines of the regional Animal Ethics Committee.

Chemicals. The herbs used in this study were all commercially available as dry matter and were purchased from Guizhou Tongjitang Zhongyaoyinpian Pharmaceutical Co. (Table 1). These herbs were identified by professor Lu Wu (Centre of Biochemical Engineering of Guizhou University, Guizhou, China) and professor Hua-Lei Wang (College of Agriculture of Guizhou University, Guizhou, China). The dosages of the herbs in JYT are based on the theory of Chinese Materia Medica (CMM) (5).

Preparation of JYT. In total, $440 \mathrm{~g}$ of the formulation was soaked in $4400 \mathrm{~mL}$ of $50 \%$ alcohol for $30 \mathrm{~min}$ and extracted two times under reflux for $2 \mathrm{~h}$ and $1 \mathrm{~h}$. The extracts were filtered and the filtrate was evaporated using a rotary evaporator to remove alcohol. The remains were further extracted by ligarine, and the aqueous phase was concentrated to $2.0 \mathrm{~g}$ of crude drug per millilitre. The concentrate was precipitated with $70 \%, 75 \%$, and $80 \%$ alcohol dilutions and then boiled with $0.125 \%$ active charcoal for $5 \mathrm{~min}$ and filtered. The precipitates were dissolved and diluted in $0.9 \%$ saline solution containing $1.0 \mathrm{~g}$ crude drug per millilitre of solution. The final concentration of JYT crude drug was $1.0 \mathrm{~g} / \mathrm{mL}$. The solution was filtered through a $0.22 \mu \mathrm{m}$ microhole filtering film and stored at $4{ }^{\circ} \mathrm{C}$ as JYT preparation (31). 
Table 1. Information regarding the herbs

\begin{tabular}{|c|c|c|c|c|}
\hline Herbs & Chinese name & $\begin{array}{l}\text { Origin } \\
\text { (China) }\end{array}$ & $\begin{array}{l}\text { Batch } \\
\text { number }\end{array}$ & $\begin{array}{l}\text { Dosage } \\
(\mathrm{g})\end{array}$ \\
\hline Lonicerae macranthoides Hand.-Mazz., flower & Shan yin hua & Guizhou & 130201 & $100 \mathrm{~g}$ \\
\hline Taraxacum mongolicum Hand.-Mazz., whole plant & Pu gong ying & Guizhou & 130101 & $100 \mathrm{~g}$ \\
\hline Trichosanthes kirilowii Maxim., fruit & Gualou & Hebei & 121001 & $100 \mathrm{~g}$ \\
\hline Forsythia suspensa (Thunb.) Vahl., fruit & Lian qiao & Henan & 130902 & $60 \mathrm{~g}$ \\
\hline Rheum officinale Baill., root & Da huang & Gansu & 120701 & $30 \mathrm{~g}$ \\
\hline Astragalus membranaceus (Fisch.) Bunge., root & Huang qi & Gansu & 121201 & $30 \mathrm{~g}$ \\
\hline Angelica sinensis (Oliv.) Diels., root & Dang gui & Gansu & 120101 & $20 \mathrm{~g}$ \\
\hline
\end{tabular}

Furthermore, bacterial endotoxin in JYT was determined by rabbit pyrogen test. The endotoxin, conforming to injection quality standards, did not induce pyrogen reaction in rabbits (4).

Primary culture of MECs. The procedure for primary culture of MECs has been previously described (8). In brief, mammary tissue was isolated from midpregnancy mice, and epithelial cells were obtained after mixed protease digestion of the tissue. The epithelial organoid suspension was treated with differential adhesion method and then resuspended in a growth medium consisting of DMEM/F12, $10 \%$ FBS, $100 \mathrm{IU} / \mathrm{mL}$ of penicillin, $100 \mathrm{IU} / \mathrm{mL}$ of streptomycin (Gibco), $4 \mathrm{mM}$ L-glutamine (Sigma), $5 \mu \mathrm{g} / \mathrm{mL}$ of bovine pancreatic insulin (Sigma), $10 \mathrm{ng} / \mathrm{mL}$ of cholera toxin (Sigma), and $10 \mathrm{ng} / \mathrm{mL}$ of epidermal growth factor (Sigma). The medium was changed once every $24 \mathrm{~h}$.

MTT assay for cytotoxicity of JYT. MTT assay for the monolayer culture was carried out according to the method by Mosmann (21), while the assay for the cytotoxicity of JYT on MECs cultures was performed with slight modification to the standard protocol. The cell concentration of MECs was adjusted to $5 \times 10^{4} \mathrm{cell} /$ well and then transferred into 96 -well plate for culturing for $12 \mathrm{~h}$. JYT was prepared as 11 concentrations to be added to wells (0.06$62.50 \mathrm{mg} / \mathrm{mL}$ ); each concentration was in duplicate. In each plate, four wells to which JYT was not added served as control. MECs were treated with different concentrations of JYT for $24 \mathrm{~h}$. Subsequently, $20 \mu \mathrm{L}$ of MTT solution $(5 \mathrm{mg} / \mathrm{mL})$ were added to each well and incubated for $4 \mathrm{~h}$. After washing the supernatant out, the insoluble formazan product was dissolved in DMSO. The optical density of the 96-well culture plates was then measured at $490 \mathrm{~nm}$ absorption wavelength. The optical density of formazan formed in untreated control cells were used to indicate $100 \%$ viability. The concentrations of JYT that resulted in $50 \%$ of cell death $\left(\mathrm{IC}_{50}\right)$ in both monolayer cultures were determined from dose-response curves (9). The assay was carried out with four replicates for each culture.

Cytokine measurement by ELISA. To assess the effect of JYT on the content of IL-6 and TNF- $\alpha$ secreted by MECs, the cells suspension $\left(1 \times 10^{5}\right.$ cell/well $)$ was added into 48 -well plate, and incubated with JYT and $10 \mu \mathrm{g} / \mathrm{mL}$ of LPS for $24 \mathrm{~h}$. According to the result of cytotoxicity assay, the final concentrations of JYT were set as $3910 \mu \mathrm{g} / \mathrm{mL}$, $391 \mu \mathrm{g} / \mathrm{mL}$, and $39.10 \mu \mathrm{g} / \mathrm{mL}$. Control cells were treated with LPS alone. At the end of the experiment, culture supernatants were collected following centrifugation of the cell culture media and the levels of IL- 6 and TNF- $\alpha$ were measured using cytokinespecific ELISA kits according to producers' instructions. All samples were assayed in triplicates. Absorbance was read at $450 \mathrm{~nm}$.

qRT-PCR. To determine the effect of JYT on mRNA expression of TLR4, MyD88, TRAF-6, IкB, and NIK in MECs, $500 \mu \mathrm{L}$ of MECs suspension was added into a 24 -well plate. When the cells completely spread out and grew to $80 \%$ confluence, $500 \mu \mathrm{L}$ of JYT and/or LPS were added to the MECs. After $24 \mathrm{~h}$ incubation, each group of MECs was harvested and the RNAs were isolated following the manufacturer's instruction. All of the RNAs were reverse transcribed by real-time PCR kit, and resulting cDNA was stored at $-80^{\circ} \mathrm{C}$ until amplification.

All primers (Table 2) used in this study were designed with the software 'Primer Premier 5.0' using available mouse sequences ( $\mathrm{NCBI}$ ). Relative quantities of gene transcripts were measured by qPCR using the SYBR Green I fluorophore. Two microlitres of each cDNA template were amplified in a $10 \mu \mathrm{L}$ of reaction volume at the following conditions: preheating at $95^{\circ} \mathrm{C}$ for $5 \mathrm{~min}$, followed by 40 cycles of denaturation at $95^{\circ} \mathrm{C}$ for $30 \mathrm{~s}$, annealing at $59.4^{\circ} \mathrm{C}$ (TLR4), $59.1^{\circ} \mathrm{C}$ (IкB), or $60.5^{\circ} \mathrm{C}$ (MyD88, TRAF-6 or NIK) for $30 \mathrm{~s}$, and extension at $72^{\circ} \mathrm{C}$ for $30 \mathrm{~s}$, and then final extension at $72^{\circ} \mathrm{C}$ for $2 \mathrm{~min}$. For quantitative evaluation of gene expression, TLR4, MyD88, TRAF-6, I $\kappa$, and NIK mRNA levels were normalised to Gapdh mRNA by the $2^{-\Delta \Delta C t}$ method $(24,25)$.

Statistical analyses. The quantitative data are expressed as the mean \pm standard deviation ( \pm SD). Multiple means were compared using one-way analysis of variance, the least significant difference method was applied when the variance was equal; and Dunnett's T3 test was performed when the variance was not equal. All of statistical analyses were performed using SPSS software 17.0 for Windows; differences with $\mathrm{P}<0.05$ were considered statistically significant.

\section{Results}

Cytotoxicity of JYT in MECs. To confirm JYT's safe dosage range in MECs, its effect on MECs 
viability was determined using the MTT assay. As shown in Fig. 2, the cell viability was not affected by the treatment with the concentration of $0-3.91 \mathrm{mg} / \mathrm{mL}$ of JYT; the cells spread out completely and a confluent monolayer of cobblestone shape was well-distributed and had good refraction (Fig. 1A). However, the cell viability in the concentration of 7.81-62.50 mg/mL of JYT was decreased, the cells were smaller than in the lower dose group, and their shapes became round and shrunken; the transmittance turned weaker and darker, the gaps among cells became larger than normal, and some fragments of the cells were seen (Fig. 1B). The $\mathrm{IC}_{50}$ of JYT on MECs that was calculated from doseresponse curves was equal to $12.25 \mathrm{mg} / \mathrm{mL}$, suggesting that the range of $39.10-3910 \mu \mathrm{g} / \mathrm{mL}$ JYT was safe to MECs.

Effects of JYT on LPS-induced secretion of IL-6 and TNF- $\alpha$ in MECs. Since the release of cytokines is considered to constitute an indicator of inflammatory response, the effect of JYT on LPSinduced inflammation in MECs was evaluated by measuring the secretion level of pro-inflammatory cytokines: TNF- $\alpha$ and IL-6. As shown in Fig. 3, LPS stimulation significantly induced the release of IL-6 and TNF- $\alpha$ in MECs. However, JYT treatment significantly, both concentration-dependently and concentration-independently, reduced the LPS-induced secretion of IL-6 (Fig. 3A) and TNF- $\alpha$ (Fig. 3B), indicating that JYT may inhibit inflammation in MECs. Combined with MTT results, the possibility that the anti-inflammatory activity of JYT was due to its cytoxicity could be excluded.

Effects of JYT on LPS-induced mRNAs expression of TLR4, MyD88, TRAF-6, IKB, and NIK in MECs. To investigate the mechanism of JYT anti-inflammatory activity, the mRNA expression of TLR4, MyD88, TRAF-6, IкB, and NIK was examined in mouse MECs. As shown in Fig. 4, upon LPS stimulation, mRNA expressions of TLR4, MyD88, TRAF-6, and NIK in MECs were markedly increased except I $\kappa$ B. This increase was significantly attenuated by JYT in both concentration-dependent and independent manner; however, IкB was further significantly decreased. All the results demonstrated that JYT prevented LPS-induced inflammatory response in MECs by inhibiting TLR4/MyD88/TRAF6/NIK signalling pathway (non-canonical NF- $\kappa$ B pathway) at the mRNA level; however, these results need further verification on the protein level.

Table 2. Gene-specific oligonucleotide primers used for qPCR

\begin{tabular}{|c|c|c|c|c|}
\hline $\begin{array}{l}\text { Gene } \\
\text { symbol }\end{array}$ & $\begin{array}{l}\text { Oligonucleotides }\left(5^{\prime}-3^{\prime}\right) \\
\text { F: forward; R: reverse }\end{array}$ & $\begin{array}{l}\text { Amplicon } \\
\text { (bp) }\end{array}$ & $\begin{array}{l}\text { Annealing temperature } \\
\left({ }^{\circ} \mathrm{C}\right)\end{array}$ & $\begin{array}{l}\text { Accession number } \\
\text { (GenBank) }\end{array}$ \\
\hline TLR4 & $\begin{array}{l}\text { F: AAAGTCCCTGATGACATTCC } \\
\text { R: TTTGAGAGGTGGTGTAAGCC }\end{array}$ & 179 & 59.4 & NM_021297.2 \\
\hline MyD88 & $\begin{array}{l}\text { F: ACTCGCAGTTTGTTGGATG } \\
\text { R: CACCTGTAAAGGCTTCTCG }\end{array}$ & 183 & 60.5 & NM_010851.2 \\
\hline TRAF-6 & $\begin{array}{l}\text { F: TGACGGTAAAGTGCCCAAAT } \\
\text { R: CACAAGAAACCTGCCTCCTG }\end{array}$ & 180 & 60.5 & NM_009424.2 \\
\hline I $\kappa \mathrm{B}$ & $\begin{array}{l}\text { F: CAACAGAGATGAGGGCATG } \\
\text { R: ATCAGGAAGTTTGGATGC }\end{array}$ & 100 & 59.1 & NM_010907.2 \\
\hline NIK & $\begin{array}{l}\text { F:ATGATTCTACCTCGGGACCA } \\
\text { R:TGGCTGGCTCACTTTCTACA }\end{array}$ & 120 & 60.5 & NM_016896.3 \\
\hline Gapdh & $\begin{array}{l}\text { F: GCAACTCCCACTCTTCCA } \\
\text { R: GCTCAGGGTTTCTTACTCC }\end{array}$ & 158 & -- & NM_008084.2 \\
\hline
\end{tabular}
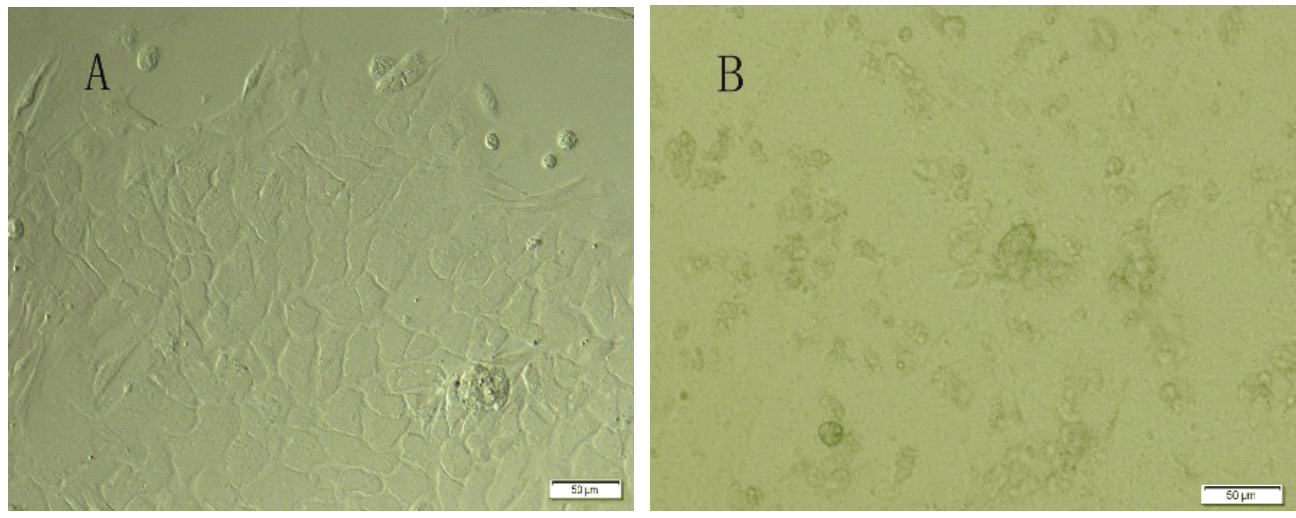

Fig. 1. A. Four-days in vitro culture of mouse MECs $(\times 200)$; cells spread out completely and a confluent monolayer of cobblestone shape was well-distributed and with good refraction. B. After $12 \mathrm{~h}$ incubation with $31.25 \mathrm{mg} / \mathrm{mL}$ JYT, the living cells were round, and part of cells was disrupted or incomplete 


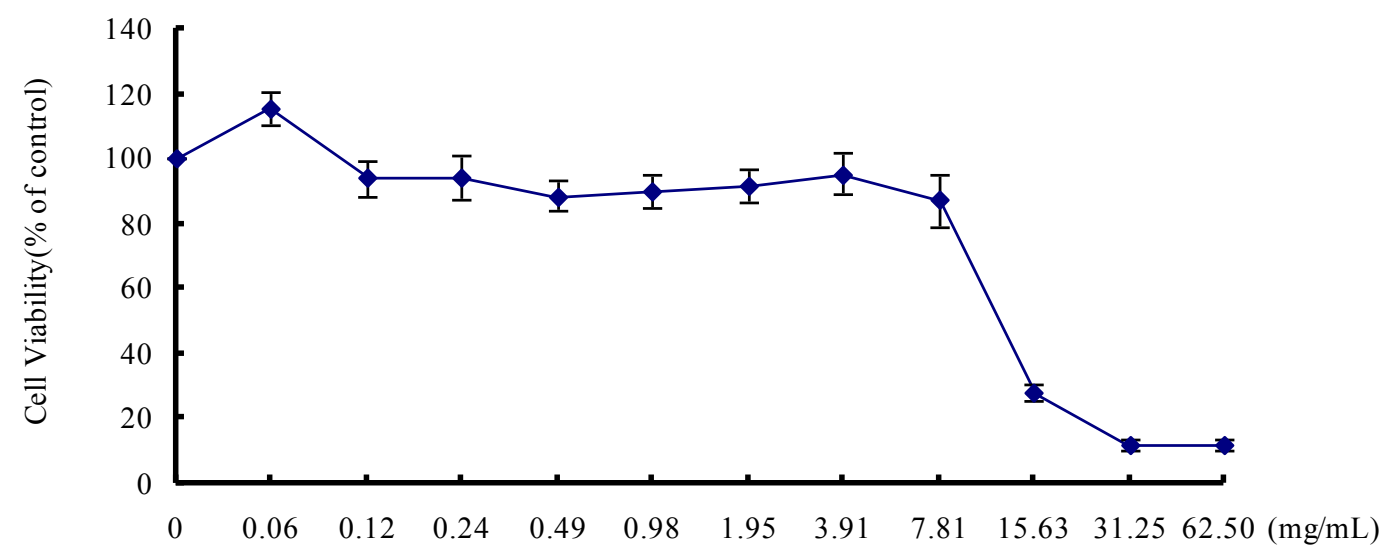

Fig. 2. Viability of the monolayer cultures of MECs determined from the MTT assay. Monolayer cultures of MECs were exposed to indicated concentrations of JYT for $24 \mathrm{~h}$. MTT assay was performed in accordance with the original method. The data were normalised to the viability of control cells. Data are presented as average with SD (error bars) from at least three independent experiments
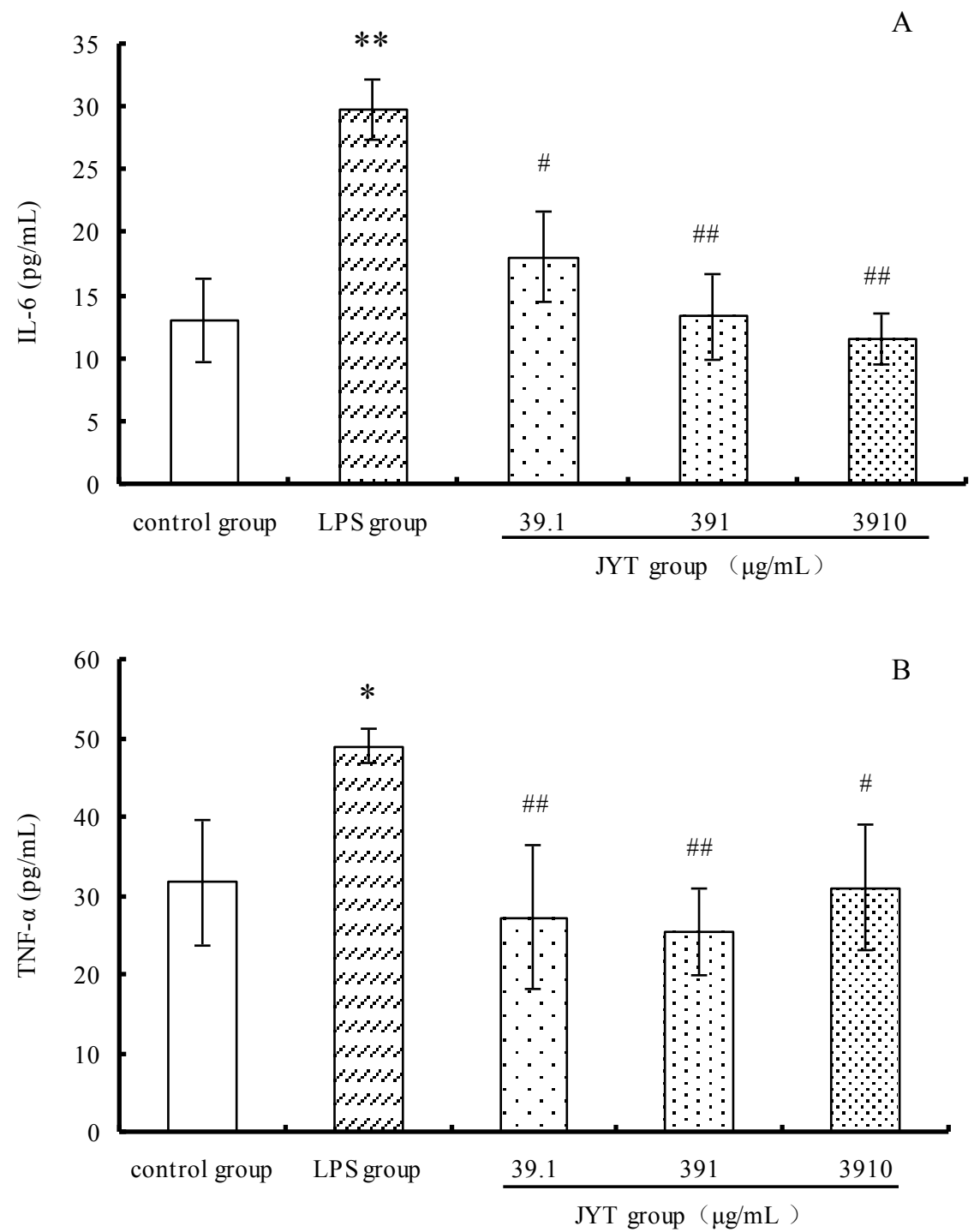

Fig. 3. Influence of JYT on IL-6 (A) and TNF- $\alpha$ (B) secretion by mouse MECs treated with LPS. Contents of IL- 6 and TNF- $\alpha$ were measured $(n=4)$ in the culture supernatants by ELISA. Data are presented as mean $\pm \mathrm{SD}$ of two independent experiments. $* \mathrm{P}<0.05, * * \mathrm{P}<0.01$, in comparison with control group. ${ }^{\#} \mathrm{P}<0.05,{ }^{\#} \mathrm{P}<0.01$, in comparison with LPS group 

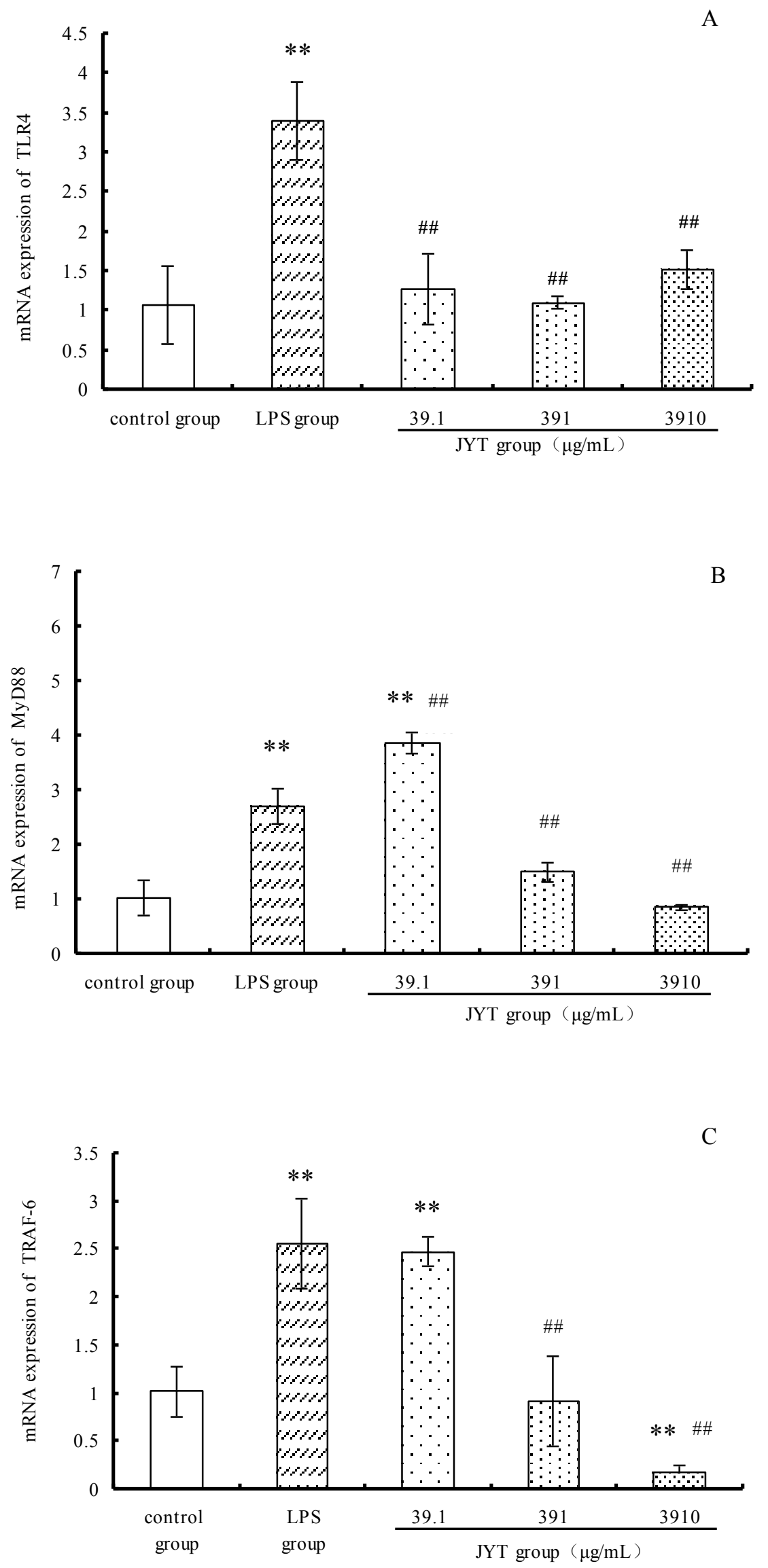

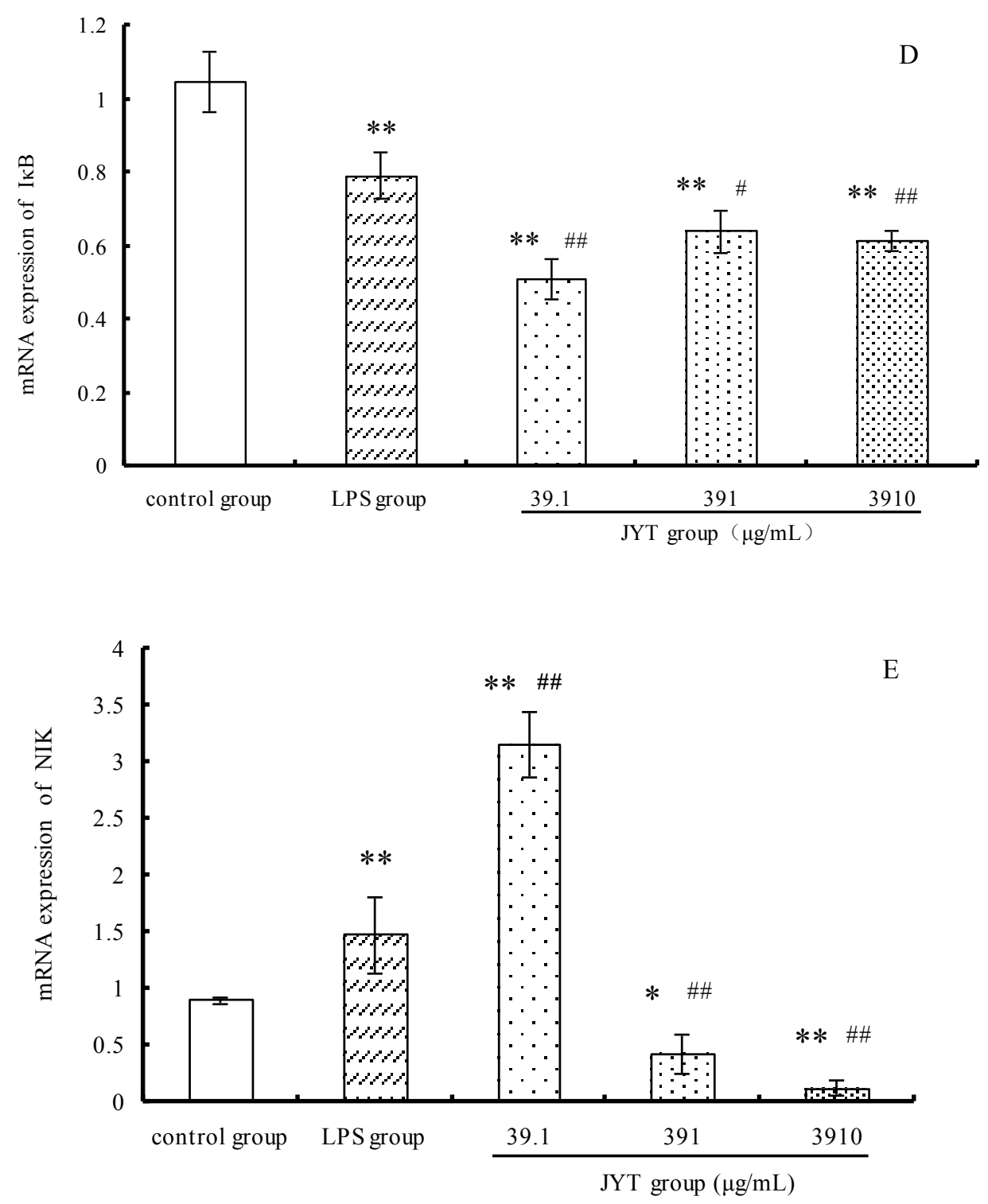

Fig. 4. Influence of JYT on the mRNAs expression of TLR4 (A), MyD88 (B), TRAF-6 (C), IאB (D), and NIK (E) of each group of treatment. The results were obtained according to the systems of housekeeping gene Gapdh. The mRNAs of TLR4, MyD88, TRAF-6, IкB, and NIK were measured in all groups $(n=3)$. Data are presented as mean $\pm \mathrm{SD}$ of two independent experiments. ${ }^{* *} \mathrm{P}<0.01$, in comparison with control group. $\# \mathrm{P}<0.05$, \#\# $\mathrm{P}<0.01$, in comparison with LPS group

\section{Discussion}

According to the theory of CMM (5), Lonicerae macranthoides Hand.-Mazz., Taraxacum mongolicum Hand.-Mazz., Rheum officinale Baill., Forsythia suspensa (Thunb.) Vahl. can clear away heat and toxic materials; Trichosanthes kirilowii Maxim., Astragalus membranaceus (Fisch.) Bunge. subdue inflammatory swelling and relieve stagnant "Qi" and "Blood"; Rheum officinale Baill., Angelica sinensis (Oliv.) Diels. can regulate and promote blood flow. All of these effects are beneficial in the treatment of mastitis and subcutaneous swelling abscesses in TCM. To support the traditional use of JYT, many studies on the activities of these herbs have been performed. It has been reported that the combination of Dandelion
(Taraxacum mongolicum Hand.-Mazz., whole plant; Lonicera japonia Thunb., flower; Forsythia suspensa (Thunb.) Vahl.; fruit of Salvia miltiorrhiza Bge.; baicalin of Scutellaria baicalensis Georgi.) can all be effective against the swelling of the auricle caused by xylene, having a good effect in the treatment of clinical mastitis (cure rate $48.39 \%$, effective rate $77 \%$ ); it also has an excellent effect on subclinical mastitis (cure rate $70.96 \%$ ) (10). Taraxacum mongolicum Hand.-Mazz. shows anti-inflammatory activity through the inhibition of TNF- $\alpha$ and IL-1 production, and COX-2 expression (15). Lonicerae macranthoides Hand.-Mazz. is a safe and mild antiinflammatory agent for treating various inflammatory disorders. Its different extracts can inhibit arachidonic acid ear oedema, rat cotton pellet granuloma, and pro- 
inflammatory cytokines expression $(12,29)$ in inflammatory model in vitro or in vivo. These findings suggest that JYT has potential benefits for TLR4 signalling of LPS-induced MECs.

In our study, we preliminarily determined the appropriate concentration ranges of JYT by microscopic cytopathic observation and MTT assay. The safe concentration of JYT was $0.49 \mathrm{mg} / \mathrm{mL}$ and the $\mathrm{IC}_{50}$ of JYT was $12.25 \mathrm{mg} / \mathrm{mL}$. According to the regression curves estimated from the data, the high dose group, the middle dose group, and the low dose group of JYT was designated as $3910 \mu \mathrm{g} / \mathrm{mL}$, $391 \mu \mathrm{g} / \mathrm{mL}$, and $39.10 \mu \mathrm{g} / \mathrm{mL}$, respectively. The subsequent experiments were conducted on the basis of the three concentration gradients of JYT. In addition, the effect of $10 \mu \mathrm{g} / \mathrm{mL}$ LPS on cell viability, permeability of cell membrane, and cell morphology was determined, and the results indicated that it had no effect on the above parameters (the data was not reported in this research).

Nowadays, available data indicate that MECs are able to release neutrophil-mobilising chemokines and pro-inflammatory cytokines upon bacterial stimulation, which plays a significant role in the occurrence and progression of mastitis $(23,27,33)$. The release of pro-inflammatory cytokines is therefore considered to constitute an indicator of the inflammatory response. MECs could be induced to secrete IL-1 $\beta$, IL-6, IL-8, and TNF- $\alpha$. This was found by Pareek et al. (23) and Wellnitz and Kerr (33). In our previous laboratory study (8), we found that mouse MECs can respond to the presence of LPS $(10 \mu \mathrm{g} / \mathrm{mL})$ and significantly up-regulate the release of TNF- $\alpha$ and IL-6. Using the LPS-stimulated infection model, we investigated the effect of JYT addition to the LPS-stimulated culture on production of TNF- $\alpha$ and IL- 6 . The results suggested that appropriate concentrations of JYT could downregulate the secretion of TNF- $\alpha$ and IL- 6 , which demonstrates that JYT could inhibit the inflammatory response in MECs.

We have also demonstrated that LPS can mediate TLR4 signalling in MEC, leading to the production of TNF- $\alpha$ and IL-6 (8). In TLRs signalling pathway, TLR4 specifically recognises LPS, and forms LPSTLR4 complex, which results in initiating intracellular signalling pathway, including the activation of MyD88 and TRAF-6, and NF- $\kappa$ B. Finally, it mediates the release of pro-inflammatory cytokines (TNF- $\alpha$ and IL-6). NF- $\kappa \mathrm{B}$ is a critical transcription factor for the release of cytokines. Both the canonical (IkB activation) and non-canonical (NIK activation) nuclear factor $-\kappa \mathrm{B}(\mathrm{NF}-\kappa \mathrm{B})$ signalling pathways could mediate the nuclear translocation of $\mathrm{NF}-\kappa \mathrm{B}(6,28)$. In the canonical NF- $\mathrm{B}$ pathway, NF$\kappa \mathrm{B}$ in unstimulated cells is sequestered in the cytosol via interaction with inhibitory $\mathrm{I} \kappa \mathrm{B}$ proteins, when cells receive pathological stimuli. I $\mathrm{B}$ proteins are phosphorylated by I $\mathrm{I} B$ kinase (IKK) and phosphorylation of $\mathrm{I} \kappa \mathrm{B}$ proteins results in their ubiquitination and degradation, which subsequently releases sequestered $\mathrm{NF}-\kappa \mathrm{B}$, leading to its translocation to the nucleus. In the non-canonical NF$\kappa \mathrm{B}$ pathway, NIK, together with a downstream

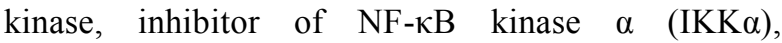
induces phosphorylation-dependent ubiquitination and processing of p100 and generates its respective mature proteins, $\mathrm{p} 50$ and $\mathrm{p} 52$, which results in the nuclear translocation of sequestered NF- $\mathrm{NB}$ members. Finally, both pathways induce the expression of various pro-inflammatory cytokines (such as TNF- $\alpha$, IL-1 $\beta$, and IL-6 ).

In order to determine which changes of gene expression influence NF- $\mathrm{NB}$ nuclear translocation in LPS-induced MECs, and whether JYT exerts an effect on the expression of these genes, the mRNA expression of TLR4, MyD88, TRAF-6, I $\kappa$ B, and NIK was determined. The results indicated that the treatment of MECs with LPS can directly contribute to a significant increase in TLR4, MyD88, TRAF-6, and NIK mRNA, except I $\mathrm{B}$, which was significantly down-regulated. These findings were consistent with previously published data $(11,37)$. Furthermore, appropriate concentrations of JYT could inhibit the increase in TLR4, MyD88, TRAF-6, and NIK expression in MECs stimulated with LPS. Surprisingly, we found that JYT could not up-regulate but further inhibit the expression of I $\mathrm{B}$ mRNA, which we had not expected. Generally, only increase in $\mathrm{I} \kappa \mathrm{B}$ expression may inhibit the release of $\mathrm{NF}-\kappa \mathrm{B}$ from the I $\mathrm{B}$ complex and further reduce the cytokine (TNF- $\alpha$ and IL-6) production. Thus, it is possible that JYT attenuates LPS-induced NF- $\mathrm{B}$ nuclear translocation in MECs and inhibits its action. However, the mRNA expression of NIK was downregulated, which means that the content of NIK protein would be decreased and could further inhibit ubiquitination and processing vitiation of TLR4/MyD88/TRAF-6/NIK pathway (nocanonical NF- $\kappa$ B pathway), but not TLR4/MyD88/TRAF-6/IкB pathway (canonical NF- $\mathrm{B}$ pathway). Both pathways are directly or indirectly contributing to blocking further intracellular signalling pathways. Finally, it suppresses the activation of the NF- $\kappa \mathrm{B}$ signalling pathway and further inhibits the release of $\mathrm{TNF}-\alpha$ and IL-6.

In the present study we preliminarily demonstrated that JYT attenuates the inflammatory response by inhibiting the activation of TLR4/MyD88/TRAF-6/NIK pathway at the mRNA level. This will lay a foundation for further research on the molecular mechanisms of JYT actions at the protein level. Our results also suggest that JYT may be a useful agent for preventing the release of cytokines in MEC, which plays a vital role in the development of mastitis. Further studies will be 
conducted to better understand those key responses in order to propose new vaccinal or therapeutic strategies against mastitis.

Conflict of Interests Statement: The authors declare that there is no conflict of interests regarding the publication of this article.

Financial Disclosure Statement: This study was supported by the National Natural Science Foundation of China (No.31060347) and (No.31260618), the innovative talent team construction project of Guizhou Province (qian-ke-he-ren-cai-tuan-dui (2012) 4007), and science and technology cooperation plan of Guizhou (Qian-Ke-He LH zi (2015)7672 hao).

Animal Rights Statement: The experiment was approved by the Guizhou Laboratory Animal Engineering Technology Center.

\section{References}

1. Akira S., Uematsu S., Takeuchi O.: Pathogen recognition and innate immunity. Cell 2005, 124, 783-801.

2. Akira S.: Innate immunity to pathogens: diversity in receptors for microbial recognition. Immunol Rev 2009, 227, 5-8.

3. Barlow J.: Mastitis therapy and antimicrobial susceptibility: a multispecies review with a focus on antibiotic treatment of mastitis in dairy cattle. J Mammary Gland Biol Neopl 2011, $16,383-407$.

4. Chen Q.: Methodology on Chinese medicinal pharmacology. In: Toxicity and safety experiment method of traditional Chinese medicine, Beijing, 2000, pp. 169-170.

5. Liu Z.J., Xu J.Q.: Traditional Chinese veterinary science. In: Traditional Chinese medicine and prescription, Beijing, 2012, pp. 119-133, 155-157, 163, 176, 231, 234.

6. Gilmore T.D.: Introduction to NF-kB: players, pathways, perspectives. Oncogene 2006, 25, 6680-6684.

7. Günther J., Koczan D., Yang W., Nürnberg G., Repsilber D., Schuberth H.J., Park Z., Maqbool N., Molenaar A., Seyfert H.M.: Assessment of the immune capacity of mammary epithelial cells: comparison with mammary tissue after challenge with Escherichia coli. Vet Res 2009, doi: 10.1051/vetres/2009014

8. He C.L., Yi Q., Li Y.F., Yang H., Wang L.: Toll-like receptor4 , but not toll-like receptor-2 mediates secretion of tumour necrosis factor $\alpha$ and interleukin- 8 in lipopolysaccharidestimulated mouse mammary epithelial cells. Bull Vet Inst Pulawy 2013, 57, 393-397.

9. Ho W.Y., Yeap S.K., Ho C.L., Rahim R.A., Alitheen N.B.: Development of multicellular tumor spheroid (MCTS) culture from breast cancer cell and a high throughput screening method using the MTT assay. PLoS One 2012, doi: 10.1371 /journal. pone. 0044640 .

10. Jin Z.H., Xiao X.L., Xue Z.Y.: Studies on the combination injectable solution of dandelion. Acta Vet Zootechn Sinica 2005, 36, 402-406

11. Jiang H., ZhangY., Wang C.: Effect of yiqi huoxue recipe containing drug-serum on the Toll-Iike receptor- 4 and its downstream signalling components MyD88 as well as the tumor necrosis factor receptor related factor-6 in human vein endothelial cells. Zhongguo Zhong Xi Yi Jie He Za Zhi 2010, 30, 519-522. (in Chinese)

12. Kang O.H., Choi Y.A., Park H.J., Lee J.Y., Kim D.K., Choi S.C., Kim T.H., Nah Y.H., Yun K.J., Choi S.J., Kim Y.H., Bae K.H., Lee Y.M.: Inhibition of trypsin-induced mast cell activation by water fraction of Lonicera japonica. Arch Pharm Res 2004, 27, 1141-1146.

13. Kawai T., Akira S.: The role of pattern-recognition receptors in innate immunity: update on Toll-like receptors. Natl Immunol 2010, 11, 373-384.

14. Kawai T., Adachi O., Ogawa T., Takeda K., Akira S.: Unresponsiveness of MyD88-deficient mice to endotoxin. Immunity 1999, 11, 115-122.

15. Koh Y.J., Cha D.S., Ko J.S., Park H.J., Choi H.D.: Antiinflammatory effect of Taraxacum officinale leaves on lipopolysaccharide-induced inflammatory responses in RAW 264.7 cells. J Med Food 2010, 13, 870-878.

16. Lahouassa H., Moussay E., Rainard P., Riollet C.: Differential cytokine and chemokine responses of bovine mammary epithelial cells to Staphylococcus aureus and Escherichia coli. Cytokine 2007, 38, 12-21.

17. Lomaga M.A., Yeh W.C., Sarosi I., Duncan G.S., Furlonger C., Ho A., Morony S., Capparelli C., Van G., Kaufman S., van der Heiden A., Itie A., Wakeham A., Khoo W., Sasaki T., Cao Z., Penninger J.M., Paige C.J., Lacey D.L., Dunstan C.R., Boyle W.J., Goeddel D.V., Mak T.W.: TRAF6 deficiency results in osteopetrosis and defective interleukin-1, CD40, and LPS signaling. Genes Dev 1999, 13, 1015-1024.

18. Martino F., Tschoop J.: NLRs join TLRs as innate sensors of pathogens. Trends Immunol 2005, 26, 449-454.

19. Medzhitov R.: Origin and physiological roles of inflammation. Nature 2008, 454, 428-435.

20. McGettrick A.F., O'Neill L.A.: Localisation and trafficking of Toll-like receptors: an important mode of regulation. Curr Opin Immunol 2010, 22, 20-27.

21. Mosmann T.: Rapid colorimetric assay for cellular growth and survival: application to proliferation and cytotoxicity assays. J Immunol Methods 1983, 65, 55-63.

22. Paape M., Mehrzad J., Zhaom X., Detilleux J., Burvenich C.: Defense of the bovine mammary gland by polymorphonuclear neutrophil leukocytes. J Mammary Gland Biol Neopl 2002, 7 , 109-121.

23. Pareek R., Wellnitz O., Van Dorp R., Burton J., Kerr D.: Immunorelevant gene expression in LPS-challenged bovine mammary epithelial cells. J Appl Genet 2005, 46, 171-177.

24. Pfaffl M.W.: A new mathematical model for relative quantification in real-time RT-PCR. Nucleic Acids Res 2001, 29 , e45.

25. Ramakers C., Ruijter J.M., Deprez R.H., Moorman A.F.: Assumption-free analysis of quantitative real-time polymerase chain reaction (PCR) data. Neurosci Lett 2003, 339, 62-66.

26. Reena Mukherjee R., De U.K., Ram G.C.: Evaluation of mammary gland immunity and therapeutic potential of Tinospora cordifolia against bovine subclinical mastitis. Trop Anim Health Prod 2010, 42, 645-651.

27. Strandberg Y., Gray C., Vuocolo T., Donaldson L., Broadway M., Tellam R.: Lipopolysaccharide and lipoteichoic acid induce different innate immune responses in bovine mammary epithelial cells. Cytokine 2005, 31, 72-86.

28. Sun S. C.: The noncanonical NF-kB pathway. Immunol Rev 2012, 246, 125-140.

29. Tae J., Han S.W., Yoo J.Y., Kim J.A., Kang O.H., Baek O.S., Lim J.P., Kim D.K., Kim Y.H., Bae K.H., Lee Y.M.: Antiinflammatory effect of Lonicera japonica in proteinaseactivated receptor 2-mediated paw edema. Clin Chim Acta 2003, 330, 165-171.

30. Tang J.J., He R.X., Wang L.: Preparation, detection and pharmacodynamics of jin-ying-huang-gui injection on mastitis in dairy cattle. Chin J Vet Med 2014, 50, 78-81.

31. Wang L., He C.L., He B.K., Guo Q., Xiao C.G., Yi Q.: Effects of Jin-Ying-Tang on Staphylococcus aureus-induced mastitis in rabbit. Immunopharmacol Immunotoxicol 2012, 34, 786-793.

32. Wellnitz O., Bruckmaier R.M.: The innate immune response of the bovine mammary gland to bacterial infection. Vet J 2012, $192,148-152$. 
33. Wellnitz O., Kerr D.E.: Cryopreserved bovine mammary cells to model epithelial response to infection. Vet Immunol Immunopathol 2004, 101, 191-202.

34. Yang H., Zhang X.Y., Wang L.: Antibacterial effects of jinying-huang-gui injection to Staphylococcus aureus. Chin J Anim Vet Sci 2013, 44, 169-173.

35. Yi Q., He B.K., Wang L., Guo Q., Zhu W.: Effects of traditional chinese medicine compound on the phagocytosis of phagocyte in mice. Heilongjiang Anim Sci Vet Med 2010, 363, $140-141$.
36. Zhang G., Ghosh S.: Toll-like receptor-mediated NF-kappaB activation: a phylogenetically conserved paradigm in innate immunity. J Clin Invest 2001, 107, 13-19.

37. Zhao B.S, Huo H.R., Ma Y.Y., Liu H.B., Li L.F., Sui F., Li C.H., Guo S.Y., Jiang T.L.: Effects of 3-phenyl-propenal on the expression of toll-like receptors and downstream signalling components on raw264.7 murine macrophages. Am J Chin Med 2008, 36, 159-169. 